\title{
SUNFlower Response to REPEATEd Foliar APPlications of PAClOBUtRAzOL $^{1}$
}

\author{
Resposta do Girassol a Repetidas Aplicações Foliares de Paclobutrazol \\ KOUTROUBAS, S.D. ${ }^{2}$, and DAMALAS, C.A. ${ }^{2}$
}

\begin{abstract}
Paclobutrazol (PBZ), a well-known growth retardant of the triazole family, is mostly used for controlling plant size and growth, resulting in more desirable compact plants for floricultural purposes; however, limited experimental data are available for use of PBZ in field sunflower. The objective of this study was to evaluate the effect of repeated foliar applications of PBZ at rates of $50+50 \mathrm{~g} \mathrm{ha}^{-1}$ (double application) and $50+50+50 \mathrm{~g} \mathrm{ha}^{-1}$ (triple application) on sunflower morphology and productivity. PBZ applications corresponded to growth stages of four to five, five to six, and six to eight true leaves of sunflower plants, respectively. The double foliar application of PBZ reduced sunflower plant height at maturity by $4.4 \%$ (or by $11.7 \mathrm{~cm}$ ). The triple foliar application of PBZ reduced sunflower plant height at maturity by $14.4 \%$ (or by $49.2 \mathrm{~cm}$ ). However, PBZ either in the double or the triple application reduced achene yield per plant by $25.6 \%$ and $22.5 \%$ and the 100 -achene weight by $11.4 \%$ and $25.0 \%$, respectively, compared with the non-treated control. Overall, the repeated foliar applications of PBZ at the rates tested in this study, apart from providing a reduction of sunflower plant height, had major adverse effects on achene yield and weight. Thus, different application schemes of PBZ or perhaps different growth regulators should be investigated to control plant height in sunflower.
\end{abstract}

Keywords: Achene yield, growth retardants, height, lodging.

RESUMO - Paclobutrazol (PBZ) é um bem conhecido retardador de crescimento da família triazol utilizado principalmente para controlar a altura e o crescimento das plantas, resultando em individuos mais compactos, o que pode favorecer o seu manejo para fins de floricultura. No entanto, dados experimentais limitados são disponiveis em relação ao uso do PBZ em girassol em campo. O objetivo deste estudo foi avaliar o efeito de aplicações foliares repetidas de PBZ em $50+50 \mathrm{~g} \mathrm{ha}^{-1}$ (aplicação dupla) e em $50+50+50 \mathrm{~g} \mathrm{ha}^{-1}$ (aplicação tripla) sobre a altura de planta e os componentes do rendimento de girassol. Aplicações de PBZ coincidiram com as fases de crescimento de quatro a cinco, cinco a seis, e seis a oito folhas verdadeiras de girassol, respectivamente. A aplicação foliar dupla de PBZ reduziu a altura das plantas de girassol na maturidade de 4,4\% (ou 11,7 cm). A aplicação foliar tripla de PBZ reduziu a altura das plantas de girassol na maturidade de 14,4\% (ou $49,2 \mathrm{~cm}$ ). No entanto, PBZ em dupla ou tripla aplicação reduziu a produção de aquênios por planta em 25,6\% e 22,5\%, e o peso de 100 aquênios em 11,4\% e 25,0\%, respectivamente, em comparação com o controle não tratado. De modo geral, as aplicações foliares repetidas de PBZ nas doses testadas neste estudo, além de proporcionarem redução da altura da planta de girassol, mostraram efeitos adversos sobre o rendimento de aquênios de girassol. Assim, diferentes esquemas de aplicação de PBZ ou talvez diferentes reguladores de crescimento devem ser investigados para controlar a altura das plantas em girassol.

Palavras-chave: produção de aquênios, retardadores de crescimento, altura, hospedagem.

Recebido para publicação em 22.11.2014 e aprovado em 3.12.2014.

Democritus University of Thrace, GR-682 00 Orestiada, Greece, <skoutrou@agro.duth.gr>; <damalas@mail.gr>.

Planta Daninha, Viçosa-MG, v. 33, n. 1, p. 129-135, 2015 


\section{INTRODUCTION}

Sunflower (Helianthus annuus) has become an important oil crop worldwide with an average annual harvested area of more than 25 million ha in 2013 (FAOSTAT, 2014). Apart from sunflower oil that is widely used for cooking, sunflower seeds are eaten raw, roasted, cooked, dried, and ground as a snack food and also as bird food. Both oil and seeds have great nutritional value and are recommended in balanced healthy diets. Agronomically, sunflower is disadvantaged by its tall growth coupled with its relatively limited root system (Weiss, 2000), and this disadvantage is often manifested in susceptibility to lodging. Short sunflower plants with increased resistance to lodging may have advantages under adverse growth conditions and are often preferred by farmers for reasons of ease of harvest (Fick \& Miller, 1997). In addition, short sunflower plants would allow the utilization of a higher number of plants per area, which in turn would contribute to faster ground cover and better weed control.

Paclobutrazol (PBZ), a commercially available growth retardant, provides a potential means of minimizing lodging in field sunflower by reducing stem length (Koutroubas et al., 2014). However, there are limited data on the use of PBZ for reduction of plant height in field sunflower. Most evidence refers to growing ornamental sunflower in pots for floricultural purposes (potted sunflower). Previous research has shown that in potted sunflower, plants treated with PBZ at a range of rates from 40 to $80 \mathrm{mg} \mathrm{L}^{-1}$ were $6 \%$ shorter than plants of the non-treated control (Whipker \& Dasoju, 1998). Drench applications of PBZ at 2 and $4 \mathrm{mg}$ per pot produced marketable sized plants that were shorter by 26 to $36 \%$ than those of the non-treated control (Dasoju et al., 1998). PBZ affected the growth and production of ornamental sunflower grown in hydroponic cultivation by reducing final plant height and head diameter (Wanderley et al., 2007, 2014); however, high PBZ rates caused deformations in the plants and bad formation of the flowers. Under field conditions, single foliar application of PBZ at $12.5 \mathrm{~g} \mathrm{ha}^{-1}$ reduced sunflower plant height at maturity by $11.1 \%$, whereas double foliar application of PBZ at $12.5+12.5 \mathrm{~g} \mathrm{ha}^{-1}$ reduced plant height by $13.9 \%$ (Koutroubas et al., 2014).

More drastic reduction in height of sunflower plants is required to reduce the risk of lodging under field conditions. Thus, the practical importance of plant height reduction obtained by foliar applications of PBZ should be further investigated, as shown by previous research (Koutroubas et al., 2014), including factors such as split repeated applications, perhaps in higher rates or applications at different crop stages. In addition, the inconsistent performance of many plant growth regulators in the field and the diverse effects on plant growth related to the timing of application (i.e. crop growth stage), the application rate of plant growth regulators, as well as the variable effects of the environmental conditions are considered major limitations in the use of many plant growth regulators (Scarisbrick et al., 1985; Leitch \& Kurt, 1999; Elkoca \& Kantar, 2006) and require studies under diverse environmental conditions.

Data on the use of PBZ for reduction of plant height in sunflower under field conditions are limited. The available data on the use of PBZ in field sunflower showed inadequate height reduction at the rates used; therefore, they suggest further investigation. Thus, the objective of this study was to evaluate the effect of different rates of PBZ on plant height and yield components of sunflower under field conditions. Based on previous experience, foliar application of PBZ was evaluated at rates of $50+50 \mathrm{~g} \mathrm{ha}^{-1}$ and $50+50$ $+50 \mathrm{~g} \mathrm{ha}^{-1}$.

\section{MATERIALS AND METHODS}

\section{Experimental design and cropping practices}

A field experiment was carried out in 2003 $\left(1^{\text {st }}\right.$ growing season, GS) and 2004 ( $2^{\text {nd }}$ growing season, GS) in Orestiada $\left(41^{\circ} 33^{\prime} \mathrm{N}\right.$ latitude, $26^{\circ} 31^{\prime} \mathrm{E}$ longitude, $33 \mathrm{~m}$ a.s.1) in northern Greece. A local population (i.e., traditional landrace) of non-oilseed sunflower was used. The experiment was established on a clay loam soil (28.7\% clay, $46.1 \%$ silt, and $25.2 \%$ sand) with $\mathrm{pH}\left(1: 1\right.$ with $\left.\mathrm{H}_{2} \mathrm{O}\right) 6.6$, organic matter 
content 2.4\%, CEC 27.7 meq $100 \mathrm{~g}^{-1}, \mathrm{~N}-\mathrm{NH}_{4}$ 9.3 ppm, P (Olsen) 46.9 ppm, and K 457.6 ppm (0 to $30 \mathrm{~cm}$ depth). The preceding crop in the experimental area before the initiation of the experiments was sugar beet (Beta vulgaris).

Soil was prepared in mid spring of each year with conventional tillage, chisel ploughing and harrowing twice. Sunflower was sown on May 3, 2003 and April 25, 2004 at a seeding rate of $7 \mathrm{~kg} \mathrm{ha}^{-1}$ with rows spaced $75 \mathrm{~cm}$ apart and plants on the row spaced $30 \mathrm{~cm}$ apart. This sowing pattern followed the usual practice of farmers in the area, yielding a crop density of 44,400 plants ha ${ }^{-1}$. Plots consisted of 4 rows of the crop, $8 \mathrm{~m}$ long each. Nitrogen (N) at $50 \mathrm{~kg}$ $\mathrm{ha}^{-1}$ in the form of ammonium sulphate, phosphorus pentoxide $\left(\mathrm{P}_{2} \mathrm{O}_{5}\right)$ at $50 \mathrm{~kg} \mathrm{ha}^{-1}$ in the form of superphosphate, and potassium oxide $\left(\mathrm{K}_{2} \mathrm{O}\right)$ at $50 \mathrm{~kg} \mathrm{ha}^{-1}$ in the form of potassium sulfate were broadcast applied and incorporated into the soil before sowing. The crop was irrigated twice: once at the early growth stages of the crop and once before flowering. Weeds were controlled manually during the early crop growth.

In the $1^{\text {st }} \mathrm{GS}, \mathrm{PBZ}\left(\mathrm{BONZI}^{\circledR} 4 \mathrm{SC}\right.$, Syngenta Hellas) was applied twice at $50+50 \mathrm{~g}$ a.i. ha ${ }^{-1}$ 33 days after sowing, when plants had five to six true leaves (BBCH 15-16) (Meier, 2001), and 10 days later. A non-treated control was included for comparison. In the $2^{\text {nd }} \mathrm{GS}$, an extra application of PBZ was made to better clarify the proper application scheme. Thus, in the $2^{\text {nd }} \mathrm{GS}, \mathrm{PBZ}$ was applied three times at $50+50+50$ g a.i. ha ${ }^{-1}$. In this case, the first application took place 26 days after sowing, at four to five true leaves (BBCH 14-15) of sunflower plants; the second application took place two weeks after the first one, at five to six true leaves, and the third application took place 10 days later (within six to eight true leaves). The treatments were arranged in a randomized complete block design with four replications. All PBZ treatments were applied with a portable hand-held field plot sprayer at $250 \mathrm{kPa}$ using a water carrier volume of $500 \mathrm{~L} \mathrm{ha}^{-1}$.

\section{Data collection}

Plant height, number of stem nodes, and stem diameter were measured at maturity using 10 plants from each plot labelled 2 days prior to the application of PBZ. Plant height was measured from the soil surface to the top of the uppermost plant organ. Stem diameter measurements were taken from the second internode of the plants. Three plants per plot were sampled at flowering and maturity. The aboveground biomass of the plants was harvested and separated into leaves, stems, and capitula. At maturity, capitula were partitioned into vegetative parts and achenes. Achenes were separated by hand into filled and unfilled ones, and the number of achenes was counted in each group. All plant samples were oven-dried at $70{ }^{\circ} \mathrm{C}$ to constant weight and weighed. Achene yield (expressed as $\mathrm{g}$ per plant) was determined on the basis of the filled achenes. In addition, the percentage of achene oil was determined with the Soxhlet extraction method according to the official methods of the American Oil Chemists' Society (AOCS, 1983).

\section{Data analysis}

All measured and derived data were subjected to analysis of variance (ANOVA) using one-way ANOVA with two treatments (the PBZ treatment plus the non-treated control) and four replications according to Steel $\&$ Torrie (1980). Because there was an extra application of PBZ in the $2^{\text {nd }} \mathrm{GS}$, the data were analyzed separately for each year. Differences between means were compared for each variable with the least significant difference (LSD) at 5\% level of significance.

\section{RESULTS AND DISCUSSION}

Figure 1 shows meteorological data during the two growing seasons of the experiment. Although total seasonal rainfall was similar in the two years $\left(188.3 \mathrm{~mm}\right.$ in the $1^{\text {st }} \mathrm{GS}$ and $180.1 \mathrm{~mm}$ in the $\left.2^{\text {nd }} \mathrm{GS}\right)$, differences in rainfall distribution between growing seasons were recorded. However, these differences did not affect considerably sunflower growth because of the artificial irrigation applied. Mean temperature during the whole growing season was $20.8{ }^{\circ} \mathrm{C}$ in the $1^{\text {st }} \mathrm{GS}$ and $20.2{ }^{\circ} \mathrm{C}$ in the $2^{\text {nd }}$ GS.

Plant height, number of nodes, and stem diameter were affected by PZB treatments. In 


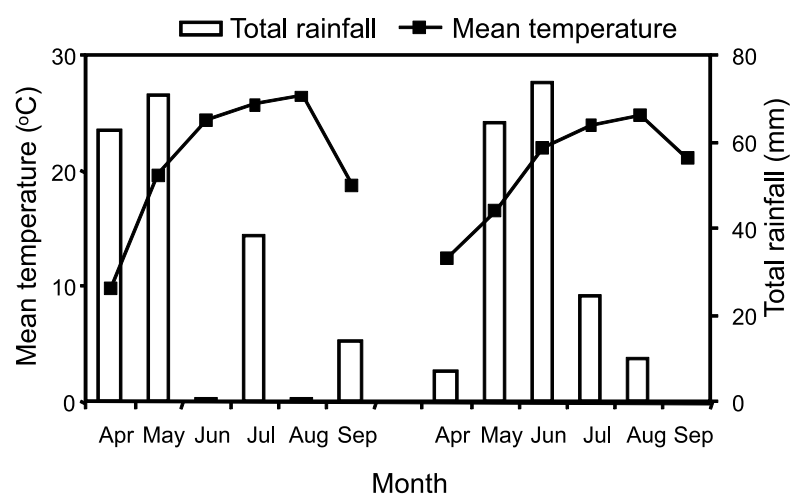

Figure 1 - Mean monthly air temperature and cumulative rainfall per month during the experiment.

the $1^{\text {st }}$ GS, there was significant reduction of plant height by $4.4 \%$ (or by $11.7 \mathrm{~cm}$ ) with the double application of PBZ compared with the non-treated control (Figure 2A). In the $2^{\text {nd }} \mathrm{GS}$, the triple application of $\mathrm{PBZ}$ reduced plant height by $14.4 \%$ (or by $49.2 \mathrm{~cm}$ ) compared with the non-treated control. The reduction in plant height was accompanied by a significant reduction in the number of stem nodes per plant only in the $2^{\text {nd }}$ GS (Figure 2B), whereas stem diameter was not affected significantly by the application of PBZ in either year (Figure 2C).

The aboveground dry weight of sunflower plants treated with PBZ did not differ significantly at flowering from that of the nontreated control in either year (Figure 3A). At maturity, there was a decreasing trend in the aboveground dry weight compared with the non-treated control, but the difference was significant only with the triple application of $\mathrm{PBZ}$ in the $2^{\text {nd }} \mathrm{GS}$ (Figure 3B). The achene yield and yield components were affected by PBZ treatments. In both years, PBZ treatments resulted in significantly reduced achene yield per plant compared with the non-treated control (Figure 4A). This reduction was $25.6 \%$ with the double application of PBZ ( $1^{\text {st }}$ GS) and $22.5 \%$ with the triple application of PBZ $\left(2^{\text {nd }}\right.$ GS). Similarly, PBZ treatments resulted in reduced 100-achene weight (based on filled achenes) by $11.4 \%$ in the $1^{\text {st }}$ GS and by $25.0 \%$ in the $2^{\text {nd }}$ GS (Figure 4B). However, an inconsistent response between years was observed for the number of filled achenes per capitulum. While the double application of PBZ $\left(1^{\text {st }}\right.$ GS) reduced significantly the number of filled achenes per capitulum, the triple application $\left(2^{\text {nd }} G S\right)$ did not affect that trait significantly compared with the non-treated control (Figure 4C).

The application of PBZ showed a significant increase of $\mathrm{N}$ in achenes in the $1^{\text {st }} \mathrm{GS}$ compared with the non-treated control. On the other hand, a reverse trend was observed in the $2^{\text {nd }} G S$, although the difference between
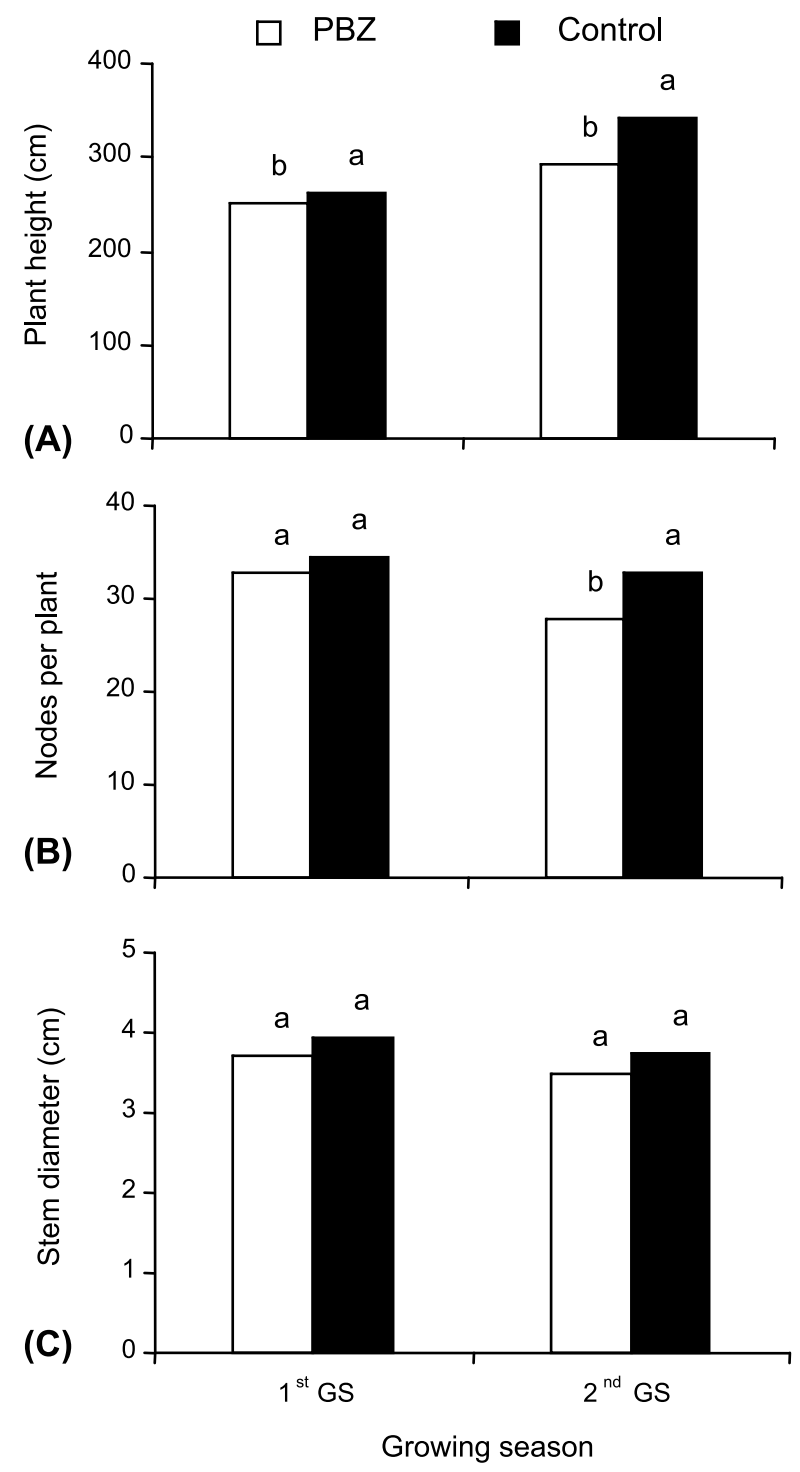

Figure 2 - (A) Plant height, (B) number of nodes, and (C) stem diameter of sunflower plants at maturity as influenced by repeated foliar applications of PBZ $\left(50+50 \mathrm{~g} \mathrm{ha}^{-1}\right.$ in the $1^{\text {st }}$ growing season, GS and $50+50+50 \mathrm{~g} \mathrm{ha}^{-1}$ in the $2^{\text {nd }}$ growing season, GS). Columns within GS with the same letter indicate values that are not significantly different at $\mathrm{P}=0.05$. 


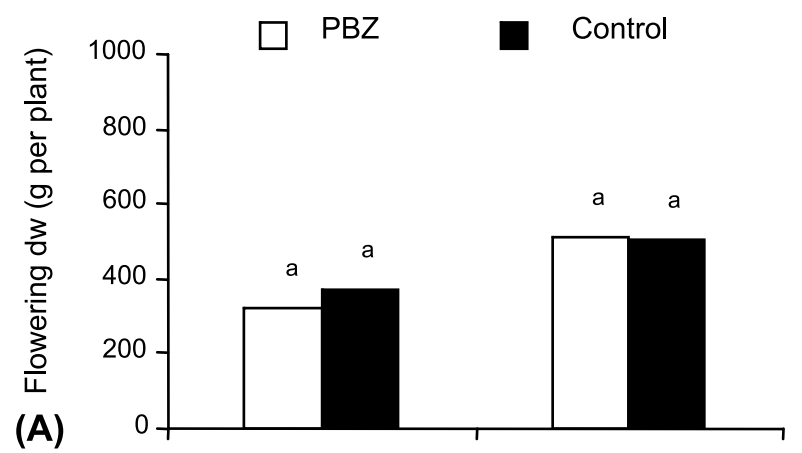

other growth parameters (Koutroubas et al., 2014). However, this reduction in sunflower plant height was considered inadequate from a practical point of view (i.e., in terms of reducing lodging risk and assisting in mechanical harvest). In the present study, a considerable reduction in sunflower plant height (by $49.2 \mathrm{~cm}$ ) was observed with the triple application of PBZ. Nevertheless, this

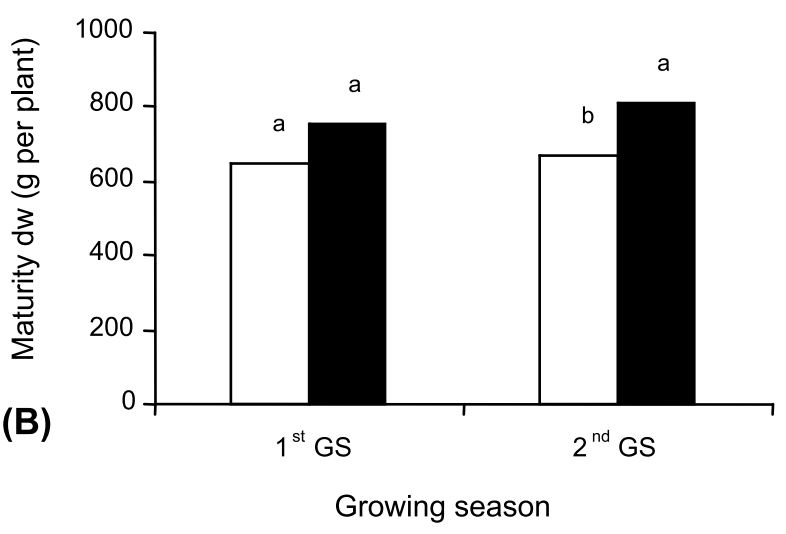

Figure 3 - Above ground dry weight of sunflower plants at (A) flowering and (B) maturity as influenced by repeated foliar applications of PBZ $\left(50+50 \mathrm{~g} \mathrm{ha}^{-1}\right.$ in the $1^{\text {st }}$ growing season, GS and $50+50+50 \mathrm{~g} \mathrm{ha}^{-1}$ in the $2^{\text {nd }}$ growing season, GS). Columns within GS with the same letter indicate values that are not significantly different at $\mathrm{P}=0.05$.

treatments was not significant (Figure 5A). There was a slight increase of achene oil content with PBZ treatments in both years, but the effect was not significant in either year (Figure 5B).

This study provides new evidence on the use of PBZ for controlling plant height in sunflower under field conditions, given that experimental data on this topic are highly limited. Repeated foliar applications of PBZ at the rates tested in the present study provided a significant reduction in height of sunflower plants. However, in both years there was a consistent reduction in achene yield and a detrimental effect on 100-achene weight, particularly in the $2^{\text {nd }}$ GS with the triple application of PBZ. Previous research with field-grown sunflower showed that single applications of PBZ reduced final plant height by $29.1 \mathrm{~cm}$ compared with the non-treated control, without any detrimental effect on
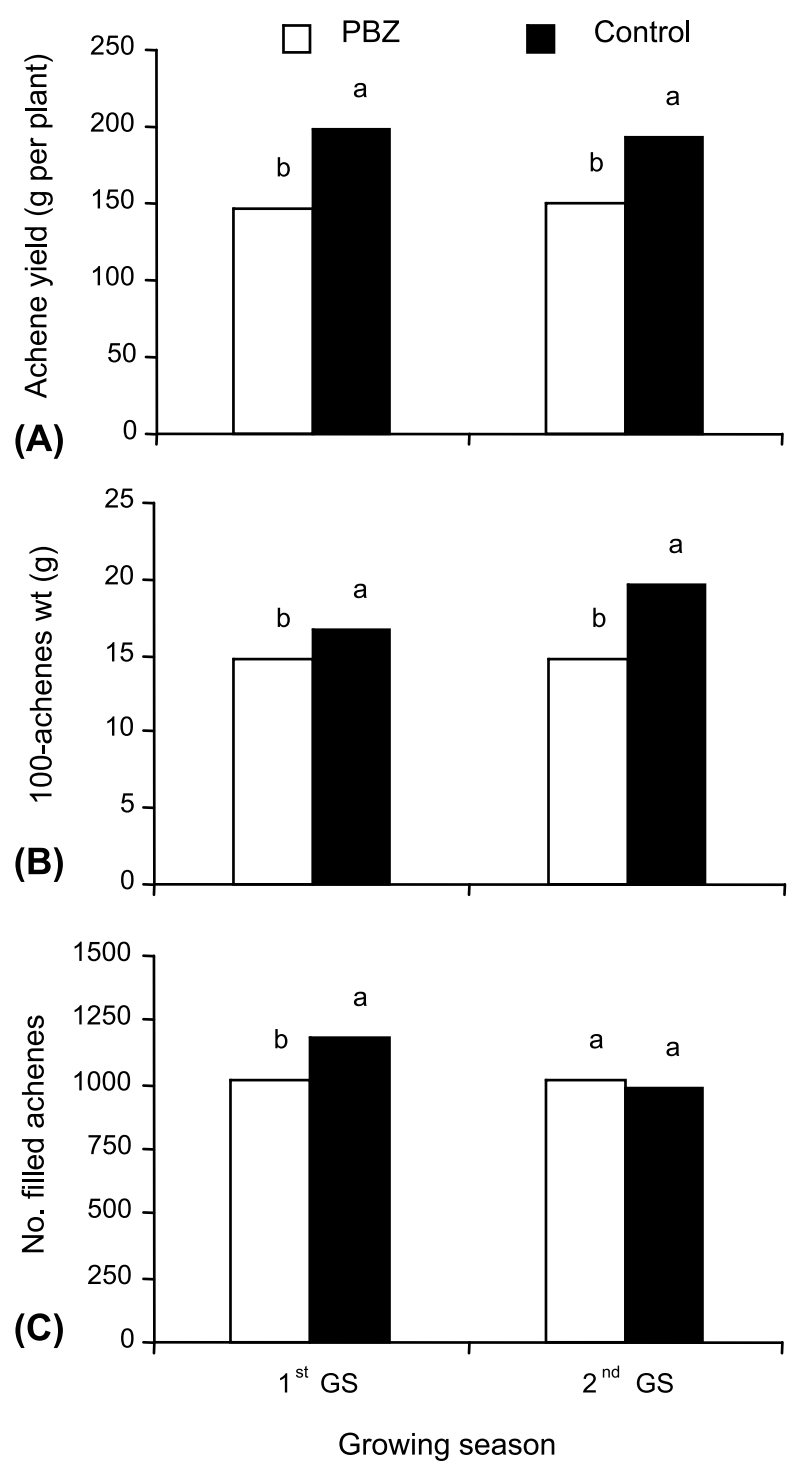

Figure 4 - (A) Achene yield, (B) 100-achene weight (filled), and (C) filled achenes per capitulum of sunflower plants as influenced by repeated foliar treatments of PBZ $(50+50 \mathrm{~g}$ ha $^{-1}$ in the $1^{\text {st }}$ growing season, GS and $50+50+50$ g ha $^{-1}$ in the $2^{\text {nd }}$ growing season, GS). Columns within GS with the same letter indicate values that are not significantly different at $\mathrm{P}=0.05$. 
treatment resulted in lower achene yield, mainly through the reduction of 100-achene weight compared with the non-treated control, which indicates a clear phytotoxic effect on sunflower plants. Seed weight in sunflower has been reported to have the highest direct positive effect on seed yield per plant (Marinkovic, 1992) along with number of seeds per head and head diameter (Yasin \& Singh, 2010). In addition, seed weight is of paramount importance in non-oilseed sunflower, because it is associated with seed size, a trait that is often used in grading seeds, with the largest ones being preferred by customers.

As far as plant height is concerned, the results of this study generally agree with those previously reported in the literature for sunflower or for other field crops. A recent study (Spitzer et al., 2011) found that sunflower plant height was reduced by as much as 63 $\mathrm{cm}$ with double application of CCC plus
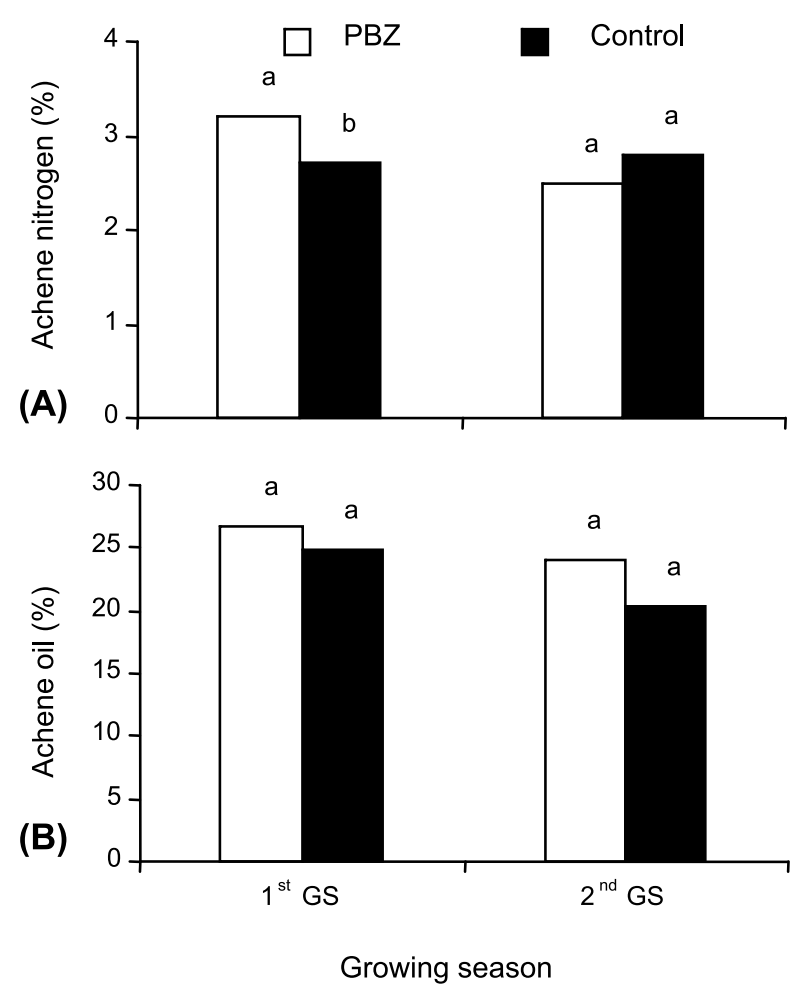

Figure 5 - (A) Achene nitrogen content and (B) achene oil content of sunflower plants as influenced by repeated foliar treatments of PBZ $\left(50+50 \mathrm{~g} \mathrm{ha}^{-1}\right.$ in the $1^{\text {st }}$ growing season, GS and $50+50+50 \mathrm{~g} \mathrm{ha}^{-1}$ in the $2^{\text {nd }}$ growing season, GS). Columns within GS with the same letter indicate values that are not significantly different at $\mathrm{P}=0.05$. ethephon and by as much as $35 \mathrm{~cm}$ with ethephon alone. Spring applications of PBZ in oilseed rape (Brassica napus) prior to a period of rapid crop development reduced plant height, but they had an adverse effect on the yield components and they offered no practical advantage in the commercial production of oilseed rape (Scarisbrick et al., 1985). By contrast, foliar application of PBZ in Ethiopian mustard (Brassica carinata), apart from reducing plant height, increased seed yield per plant primarily due to an increase in the number of siliquae (i.e., pods) per plant and secondarily due to an increase in total dry matter of plants and partitioning coefficients (Setia et al., 1995). The shortening effect of PBZ on sunflower plants appeared to be associated with the application scheme tested. The double application of PBZ reduced plant height mostly due to the reduction of the internode length, because the number of stem nodes was not affected significantly. On the other hand, the shortening effect of the triple application of PBZ was due to reduction of the number of stem nodes per plant. These results are in agreement with Weiss (2000), who reported that certain growth regulators generally reduced height of sunflower plants at maturity by affecting the internode length, although a different reaction to the chemical used or to the rate applied may exist, depending on the cultivar. In addition, Scarisbrick et al. (1985) found that PBZ significantly reduced the lengths of earlyformed internodes of oilseed rape at the base of the plant, whereas later internodes in the middle and at the top of plants became longer than those of the control. Stem diameter of sunflower plants was not affected in either year; this is in line with Sanvicente et al. (1999) who studied the influence of plant growth regulators on culm diameter of winter barley.

In conclusion, although repeated foliar applications of PBZ gave a significant reduction of sunflower plant height, it had adverse effects on achene yield and weight. Thus, repeated foliar applications at the rates tested in the present study cannot be used commercially for reducing plant height in this crop. The detrimental effects of PBZ on sunflower yield were probably associated with the specific application rates evaluated in this study. 
Therefore, different application schemes of PBZ or different growth regulators should be investigated.

\section{LITERATURE CITED}

AMERICAN OIL CHEMISTS' SOCIETY - AOCS. Official and tentative methods of the American oil chemists' society. 3.ed. Champaign, IL: AOCS, 1983.

DASOJU, S. et al. Paclobutrazol drenches control growth of potted sunflowers. HortTechnology, v. 8, n. 2, p. 235-237, 1998.

ELKOCA, E.; KANTAR, F. Response of pea (Pisum sativum L.) to mepiquat chloride under varying application doses and stages. J. Agron. Crop Sci., v. 192, n. 2, p. 102-110, 2006.

FAOSTAT. FAO Statistical Databases. Available from: $<$ http://faostat.fao.org>. Accessed: Nov. 10, 2014.

FICK, G. N.; MILLER, J. F. Sunflower breeding. In: SCHNEITER, A. A. Sunflower technology and production (Monograph 35). Madison: ASA, CSSA, SSSA, 1997. p. 395-439.

KOUTROUBAS, S. D. et al. Sunflower morphology and yield as affected by foliar applications of plant growth regulators. Intern. J. Plant Produc., v. 8, n. 2, p. 215-229, 2014.

LEITCH, M. H.; KURT, O. Effects of plant growth regulators on stem extension and yield components of linseed (Linum usitatissimum). J. Agric. Sci., v. 132, n. 2, p. 189-199, 1999.

MARINKOVIC, R. Path-coefficient analysis of some yield components of sunflower (Helianthus annuus L.), I.

Euphytica, v. 60, n. 3, p. 201-205, 1992.

MEIER, U. Growth stages of mono- and dicotyledonous plants. 2.ed. (BBCH Monograph). Berlin: German Federal Biological Research Centre for Agriculture and Forestry, 2001.
SANVICENTE, P. et al. Morphological and anatomical modifications in winter barley culm after late plant growth regulator treatment. Eur. J. Agron., v. 11, n. 1, p. 45-51, 1999.

SCARISBRICK, D. H. et al. The effect of paclobutrazol on plant height and seed yield of oil-seed rape (Brassica napus L.). J. Agric. Sci., v. 105, n. 3, p. 605-612, 1985.

SETIA, R. C. et al. Influence of paclobutrazol on growth and yield of Brassica carinata A.Br. Plant Growth Reg., v. 16, n. 1, p. 121-127, 1995.

SPITZER, T. et al. Management of sunflower stand height using growth regulators. Plant Soil Environ., v. 57, n. 8, p. 357-363, 2011.

STEEL, R. G. D.; TORRIE, J. H. Principles and procedures of statistics: A biometrical approach. 2.ed. New York: McGraw-Hill, 1980. 633 p.

WANDERLEY, C. S. et al. Effect of paclobutrazol as regulator of growth in production of flowers of sunflower in cultivo hidropônico. Ci. Agrotecnol., v. 31, n. 6, p. 1672-1678, 2007.

WANDERLEY, C. S. et al. Growth of potted sunflower in response to paclobutrazol. R. Ceres, v. 61, n. 1, p. 35-41, 2014.

WEISS, E. A. Oilseed crops. 2.ed. Oxford: Blackwell Science, 2000. 364 p.

WHIPKER, B. E.; DASOJU, S. Potted sunflower growth and flowering responses to foliar applications of daminozide, paclobutrazol, and uniconazole. HortTechnology, v. 8, n. 1, p. 86-88, 1998.

YASIN, A. B.; SINGH, S. Correlation and path coefficient analyses in sunflower. J. Plant Breed. Crop Sci., v. 2, n. 1, p. 129-133, 2010. 